\title{
Occurrence of calreticulin during the exchange of nucleohistones into protamine-type proteins in Chara vulgaris spermiogenesis
}

\author{
Katarzyna Popłońska
}

Received: 1 August 2011 / Accepted: 13 December 2011 / Published online: 25 December 2011

(C) The Author(s) 2011. This article is published with open access at Springerlink.com

\begin{abstract}
During spermiogenesis of an alga Chara vulgaris, which resembles that of animals, nucleohistones are replaced by protamine-type proteins. This exchange takes place in a spermatid nucleus during the key $\mathrm{V}$ spermiogenesis stage, in which rough endoplasmic reticulum is the site of protaminetype protein synthesis and is also the pathway guiding the proteins to their destination, nucleus. In the present work, it was shown that a chaperon protein, calreticulin (CRT), abundantly present at this significant $\mathrm{V}$ stage of spermiogenesis in a few cellular compartments, i.e., a nucleus, lumen of cisternae, and vesicles of significantly swollen ER as well as outside these structures, e.g., in Golgi apparatus, could have taken part in the process of exchange of nuclear proteins. Colocalization of two proteins, protamine-type proteins, crucial for reproduction, and CRT, was especially visible in a nucleus, mainly on its peripheries where condensed chromatin was present. Localization of protamine-type proteins and CRT in nucleus is in agreement with our previous results showing that protaminetype proteins were twofold more labelled in the peripheral area in comparison to the nucleus center occupied by noncondensed chromatin. The role of CRT in the reproduction of both plants and animals is also discussed.
\end{abstract}

Keywords Calreticulin - ER cisternae and vesicles . Immunogold technique $\cdot$ Nucleohistones $\cdot$ Protamine-type proteins $\cdot$ Spermiogenesis

Handling Editor: Adrienne R. Hardham

K. Popłońska $(\bowtie)$

Department of Cytophysiology, University of Łódź,

Pomorska 141/143,

90-236 Łódź, Poland

e-mail: popkat@biol.uni.lodz.pl

\section{Introduction}

Spermiogenesis is one of the key processes in animal and some plant organisms. This period is characterized by chromatin remodelling; nucleohistone structure, characteristic of somatic cells, is replaced by fibrillar chromatin resulting in gene silencing in mature spermatozoids (Ward 1994). This process leads to extreme chromatin condensation (Pogany et al. 1981; Ward and Coffey 1991; Daban 2000; Ausio et al. 2007) and results from the exchange of histones into protamines or other strongly basic proteins (Steger 1999; Dadoune 2003; Balhorn 2007; Worawittayawong et al. 2008; Hecht et al. 2009; Kurtz et al. 2009; Miller et al. 2010). It is a common process mostly in the case of animals from non-vertebrates, e.g., in Drosophila melanogaster (Rathke et al. 2007), and fish (Oliva and Dixon 1991; Kurtz et al. 2009) to mammals, including humans (Wouters-Tyrou et al. 1998; Ramos et al. 2008). In the case of plants, it takes place only in the organisms producing freemoving spermatozoids in water, e.g., in Marchantia polymorpha (Reynolds and Wolfe 1978) and in Marsilea vestitia (Reynolds and Wolfe 1984). The exchange of somatic, nucleus-specific histones with protamine-type proteins was also described in higher algae, in Chara corralina (Reynolds and Wolfe 1984), Chara vulgaris (Kwiatkowska and Popłońska 2002; Popłońska et al. 2007), as well as in Chara tomentosa (Kwiatkowska et al. 2002; Kwiatkowska and Popłońska 2003; Popłońska et al. 2007).

Light and electron microscopy studies of the two latter Chara species were allowed to differentiate ten spermiogenesis stages (I-X) (Kwiatkowska and Popłońska 2002; Kwiatkowska et al. 2002). Both cytochemical (Popłońska 2002) and immunocytochemical (Popłońska et al. 2007) studies of the exchange of histone proteins into protaminetype proteins in both Chara species showed that at early stages (I-IV) only histones were present while at final stages 
(IX-X) only protamine-type proteins were observed in the nuclei of differentiating spermatozoids. Moreover, the capillary electrophoresis with mature $C$. tomentosa spermatozoid extract confirmed lack of histones which were replaced by three basic protein fractions (with molecular weights 9.1, 9.6, and $11.2 \mathrm{kDa}$ ), with motility similar to that of salmon protamines. These analyses revealed small amounts of protamine-type proteins already in mid-spermiogenesis, and during the late spermiogenesis, they almost reached the maximum level. However, during $C$. tomentosa spermiogenesis, no transient proteins were observed (Kwiatkowska et al. 2002), as contrasted for example with mammals (McLay and Clarke 2003). Using Western blot method showed additional protamine-type proteins with molecular weights 3-6 kDa (Popłońska et al. 2009).

The V stage of Chara spermiogenesis is the starting point of the exchange of nucleohistones into nucleoprotamines, which is pivotal for proper chromatin condensation, leading to extremely condensed chromatin in mature spermatozoids. Ultrastructural studies of both Chara species revealed that, in the V stage, the extensive system of ER vesicles and cisternae connected with a nuclear envelope was present. Both the vesicles and the swollen cisternae are filled with dark, granular content, and the intermembrane area of a nuclear envelope also contains similar homogenous substance (Kwiatkowska 1996; Kwiatkowska and Popłońska 2002, 2003; Kwiatkowska et al. 2002). The cytochemical and immunocytochemical ER studies revealed clear staining and strong antigenic signals against protamine-type proteins which were observed in the form of parallel strands in the cytoplasm near spermatid nuclei (Popłońska et al. 2007), which confirmed the earlier hypothesis that protamine-type protein synthesis may occur in ER area (Kwiatkowska 1996; Kwiatkowska and Popłońska 2002; 2003; Kwiatkowska et al. 2002). The immunogold method revealed gold labelling of ER vesicles and cisternae at the $\mathrm{V}$ stage of spermiogenesis. Therefore, both these subdomains are the site of protamine-type protein synthesis which are subsequently transported directly to the nuclear envelope, and via endocytosis by invagination of an internal membrane of the nuclear envelope, they reach their destination, that is, a nucleus (Popłońska et al. 2009).

ER plays a crucial role in many cell processes, including storage and release of $\mathrm{Ca}^{2+}$, lipid and protein synthesis, as well as in proper folding, and post-translational modifications of the latter ones (Baumann and Walz 2001; Hebert and Molinari 2007; Michalak et al. 2009). In the ER lumen, there are perfect conditions for folding and maturation of proteins. There are great amounts of dissolved enzymatic proteins and molecular chaperons; all of them are referred to as reticuloplasmins. Among these reticuloplasmins residing in ER, there is calreticulin (CRT) which is a chaperon present both in animal (Persson et al. 2002; Park et al. 2001) and plant cells (Šamaj et al. 2008; Lenartowska et al. 2009; Jia et al. 2009). The plant CRT was extracted from spinach leaves (Menegazzi et al.
1993), barley (Chen et al. 1994), tobacco (Denecke et al. 1995), maize (Dresselhaus et al. 1996; Kwiatkowski et al. 1995), Chinese cabbage (Lim et al. 1996), Arabidopsis (Nelson et al. 1997), rice (Li and Komatsu 2000), and wheat (Jia et al. 2008). These CRTs showed high homology to their counterparts in mammals. There are some indications that CRT may also be involved in reproductive events in plants, e.g., in fertilization (Dresselhaus et al. 1996; Nelson et al. 1997; Williams et al. 1997) and embryo development (Chen et al. 1994; Borisjuk et al. 1998).

The present research aimed:

1. To determine the CRT levels at three selected stages (IV, the stage before the exchange of nuclear proteins; $\mathrm{V}$, at the beginning of exchange, and VIII, at the end of exchange) of $C$. vulgaris spermiogenesis.

2. To analyze in which spermatid domains CRT is cumulated.

3. To check whether CRT colocalizes with protamine-type proteins at the crucial V stage of spermiogenesis.

\section{Materials and methods}

Apical parts of C. vulgaris L. thallus were obtained from plants grown in an artificial pond located in Rogów Arboretum. Antheridia were taken from III-V pleuridia node counting from the top. Before the onset of the experiment, the plants were cultivated for a few days in tanks containing water from the natural environment at the photoperiod similar to natural, i.e.,

$\mathrm{L}: \mathrm{D}=14: 10$.

\section{Western blot technique}

C. vulgaris antheridia were isolated, selected (only spermatids from the $\mathrm{V}$ stage of spermiogenesis were chosen), and kept in $-20^{\circ} \mathrm{C}$. Reassembled antheridia were gently crashed in a cold glass mortar with $10 \mathrm{mM}$ Tris- $\mathrm{HCl}$ saline buffer (pH 8.0) supplemented with $10 \mathrm{mM} \mathrm{NaCl}, 5 \mathrm{mM} \mathrm{MgCl}$, $0.25 \mathrm{M}$ sucrose, $2 \mathrm{mM}$ DTT, and cocktail of protease inhibitor (Sigma). To separate antheridial filament cells from shield cells, the crashed antheridia were repeatedly washed with the buffer using Pasteur pipette. During the last washing, the antheridial filament cells were collected by centrifugation at $1,000 \times g$ for $15 \mathrm{~min}\left(4^{\circ} \mathrm{C}\right)$. Proteins were extracted from antheridial filament cells with the P-PER Plant Protein Extraction Kit (Pierce) according to the protocol and then were fractionated on $4-12 \%$ Bis Tris/MES PAGE-SDS gels (Novex) and blotted onto PVDF Membrane $0.2 \mu \mathrm{m}$ pore size (Invitrogen). Anti-CRT (anti-calregulin (N-19): goat polyclonal antibody sc-6468 raised against calregulin of human origin, Santa Cruz Biotechnology) diluted 1:200 was detected 
using chromogenic Western blot immunodetection kit (Invitrogen). Instead of the primary antibody, purified antibodies from non-immune goat serum were used as a control at the same concentration as the specific antibody.

Single labelled immunogold technique

C. vulgaris plants were fixed with $0.5 \%$ glutaraldehyde and $2.5 \%$ paraformaldehyde in $0.1 \mathrm{M}$ cacodylate buffer $(\mathrm{pH} 7.3$ ) supplemented with $0.007 \mathrm{M} \mathrm{CaCl}_{2}$ for $3 \mathrm{~h}$ at RT. The antheridia were isolated and gently squashed in a drop of heated $2 \%$ agar in cacodylate buffer. After dehydration in the ethanol series, the material was embedded in Epon 812 and Spurr mixture medium (Polysciences). Embedded antheridia of three spermiogenesis stages: early (IV), middle (V), and late (VIII) were selected. Freshly cut ultrathin sections were mounted on nickel Formvar-coated grids for EM investigations. Air-dried grids with sections were blocked with $0.5 \%$ bovine serum albumin and $0.05 \%$ Tween 20 in phosphate buffered saline (PBS) (0.01 M, pH 7.4, Sigma) for $10 \mathrm{~min}$ and then dried with tissue-paper. The sections on grids were incubated overnight at $20^{\circ} \mathrm{C}$ with the primary antibody (anticalregulin, Santa Cruz Biotechnology) diluted in an antibody diluent ( $\mathrm{pH}$ 8.0, DAKO) at 1:25 dilution. Then the grids were washed five times for $5 \mathrm{~min}$ each with the same PBS and incubated with the secondary antibody (rabbit anti-goat IgG conjugated with $20 \mathrm{~nm}$ gold [no. EM. RAG20, Polysciences]) diluted 1:70 in the antibody diluent for $1.5 \mathrm{~h}$ in the same temperature and rinsed again in PBS and distilled water (ten times for $5 \mathrm{~min}$ each). After this, sections were double-stained with uranyl acetate and lead citrate according to Reynolds (1963). The sections were also examined and photographed in a JEOL JEM-1010 transmission electron microscope.

\section{Double labelled immunogold technique}

C. vulgaris plants were fixed as above. To isolate antheridia and to prepare the material for embedding in mixture medium (Polysciences), the similar techniques to those above were used. The antheridia in the crucial middle stage of spermiogenesis (V) were selected. Further steps were similar to the single labelled immunogold technique. The sections on grids were incubated overnight at $20^{\circ} \mathrm{C}$ with the antibody (anticalregulin, Santa Cruz Biotechnology) diluted in an antibody diluent ( $\mathrm{pH}$ 8.0, DAKO) at 1:25 dilution and were incubated with the antibody (rabbit anti-goat IgG conjugated with $10 \mathrm{~nm}$ gold [no. EM. RAG20, Polysciences]) diluted 1:70 in the antibody diluent for $1.5 \mathrm{~h}$ in the same temperature. Next, the above procedure was repeated for rabbit polyclonal antibody to the protamine-type proteins isolated from antheridia of $C$. tomentosa (technique of isolation; see Popłońska et al. 2007) diluted in an antibody diluent ( $\mathrm{pH}$ 8.0, DAKO) at a 1:250 dilution and incubated with the final antibody (anti-rabbit IgG conjugated with $20 \mathrm{~nm}$ gold [no. EM.GAR20, Polysciences]) diluted 1:70 in the antibody diluent for $1.5 \mathrm{~h}$ in the same temperature.

Analysis of spermatid immunolabelling

Micrographs of 30 spermatids from the IV, V, and VIII stage were analyzed. Statistical results were estimated by Student $t$ test with the use of Microsoft Excel 2000. Differences in number of grains in the studied compartments between IV and $\mathrm{V}$ stage as well as between $\mathrm{V}$ and VIII stage of spermiogenesis are statistically significant taking $p \leq 0.05$ as the significance level. To show colocalization of protamine-type proteins with CRT, micrographs of 35 spermatids from the $\mathrm{V}$ stage were analyzed. The percentage of gold grains reflecting the colocalization of protamine-type proteins with CRT in each cellular compartment was calculated taking as $100 \%$ for grains the whole cell, as well as percentage of gold grains reflecting the colocalization of protamine-type proteins with CRT in individual cellular domain was calculated taking as $100 \%$ for grains in the given cellular domain. Statistical results were also analyzed with the use of Microsoft Excel 2000, and means \pm SE were estimated.

\section{Results}

\section{Western blot analysis}

Western blot was performed with the use of an antibody raised against human CRT with molecular weight about $55 \mathrm{kDa}$. In the extract from $C$. vulgaris antheridia from the $\mathrm{V}$ stage of spermiogenesis, two bands pointing proteins with molecular weights of about 55 and $62 \mathrm{kDa}$ were revealed (Fig. 1a, line 3). The comparison with the control serum (Fig. 1a, line 4) indicates that faint band with molecular mass about $70 \mathrm{kDa}$ did not originate from CRT polypeptide. This suggests that CRT exists in two isoforms in the studied material. Moreover, this result indicates that this antibody is specific and could be applied for the immunogold technique in our plant material.

Immunogold analyses of ultrathin sections

The same antibody, previously checked with Western blot technique, was used in immunogold analyses. At the early spermiogenesis stage (IV), both the cytoplasm and nuclei were weakly immunolabelled (Fig. 1b and Table 1). Spermatids in which the antibody to CRT was omitted were not labelled (negative control; Fig. 1c).

At the V stage - crucial for spermatozoid maturation - gold grains were mainly observed in the nuclei, in the extensive system of ER cisternae and vesicles (Figs. 1d, 2a, b, and 3a and 


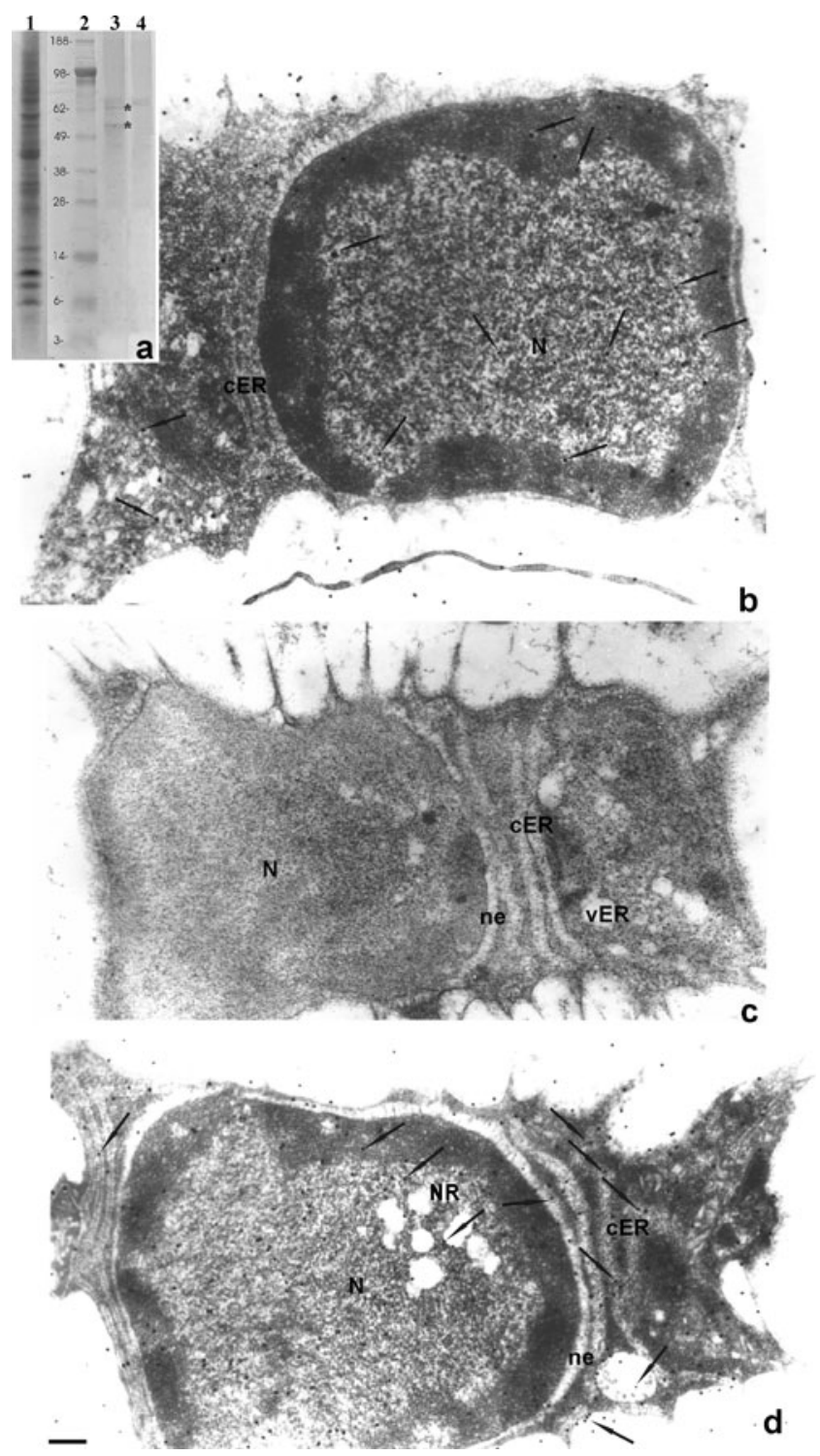

Fig. 1 Immunodetection of CRT during spermiogenesis in C. vulgaris. a Western blot analysis; line 1, SDS-PAGE electrophoretic separation of the antheridial filament cells extract; line 2, molecular mass standards and their weights in kilodaltons; line 3, Western blotting of the antheridial filament cells extract probed with the anti-human CRT antibody; line 4, CRT pre-immune serum; *Proteins revealed b ultrastructure of spermatid at IV stage of spermiogenesis in longitudinal section (immunogold technique). c Spermatid at V stage of spermiogenesis (negative control to immunogold technique). d Ultrastructure of spermatid at $\mathrm{V}$ stage of spermiogenesis in longitudinal section (immunogold technique). Arrows show localization of gold grains in particular spermatid compartment. $c E R$, endoplasmic reticulum cisternae; $v E R$, endoplasmic reticulum vesicles; $N$, nucleus; ne, nuclear envelope; $N R$, nuclear reticulum; $B a r=250 \mathrm{~nm}$

Table 1) and at the plasmalemma (Figs. $1 \mathrm{~d}$ and $2 \mathrm{~b}$ ), in the Golgi apparatus (Fig. 3a), as well as in the cell walls of adjacent spermatids (not shown). Labelling from a nucleus was observed in its peripheries adjacent to the nuclear envelope where condensed chromatin was present and at its central part where
Table 1 Number of gold grains after the use of antibody to CRT in particular C. vulgaris spermatid compartments at stages IV, V, and VIII of spermiogenesis

\begin{tabular}{llll}
\hline & Stage IV & Stage V & Stage VIII \\
\hline $\begin{array}{l}\text { Compartment } \\
\text { Endoplasmic reticulum }\end{array}$ & \multicolumn{3}{c}{ Number of grains } \\
Vesicles & $12 \pm 1.45$ & $46 \pm 1.02$ & - \\
Cisternae & $11 \pm 0.85$ & $21 \pm 0.72$ & - \\
Total & $23 \pm 1.04$ & $67 \pm 1.35$ & $8 \pm 0.8$ \\
Whole nucleus & $42 \pm 0.45$ & $127 \pm 1.4$ & $4 \pm 1.6$ \\
Nuclear envelope & $5 \pm 0.32$ & $14 \pm 0.38$ & - \\
Chromatin & & & - \\
Condensed & $20 \pm 1,22$ & $61 \pm 1.03$ & - \\
Noncondensed & $17 \pm 0.9$ & $52 \pm 0.95$ & - \\
Total & $37 \pm 0.78$ & $113 \pm 1.42$ & - \\
Cytoplasm+other & $12 \pm 1.3^{\mathrm{a}}$ & $11 \pm 0.43^{\mathrm{a}}$ & $3 \pm 0.9$ \\
$\quad$ organelles & & & \\
\hline
\end{tabular}

Values represent the mean $\pm \mathrm{SE}$; differences in number of grains in the studied compartments between IV and V stage as well as between V and VIII stage of spermiogenesis are statistically significant taking $p \leq$ 0.05 as the significance level

${ }^{\mathrm{a}}$ These differences are not statistically significant

noncondensed chromatin was located (Fig. 1d) as well as in the nuclear envelope connected with swollen rough endoplasmic reticulum (Fig. 2a, b) filled with protamine-type proteins (Popłońska et al. 2009). In noncondensed chromatin, there were aggregates of vesicles called nuclear reticulum resulting from invagination of an inner membrane of the nuclear envelope. These structures contained gold grains which were located near their peripheral part (Figs. 1d and 2b). At late spermiogenesis stage (VIII), few gold grains were identified only at plasmalemma and in poorly developed ER cisternae of significantly reduced cytoplasm (Fig. 3b, grey arrows). Within a crescent nucleus fibrillar chromatin (fibrils parallel to the nucleus long axis), no gold grains were observed, while between fibrils, where electron density was lower, few immunosignals were present (Fig. 3b, white arrows).

\section{Colocalization of protamine-type proteins and CRT}

For double immunogold labelling, anti-CRT antibody was used as the first antibody, and antibody against protaminetype proteins isolated from $C$. tomentosa antheridia followed. Spermatids in which the antibodies to the studied proteins were omitted were not labelled as before (negative control, not shown).

At the V stage, where the CRT level was the highest, gold grains from both antibodies were mostly visible in nuclei, extensive system of ER cisternae, and vesicles (Fig. 4a, b) and in Golgi apparatus (Fig. 4b). Double- 

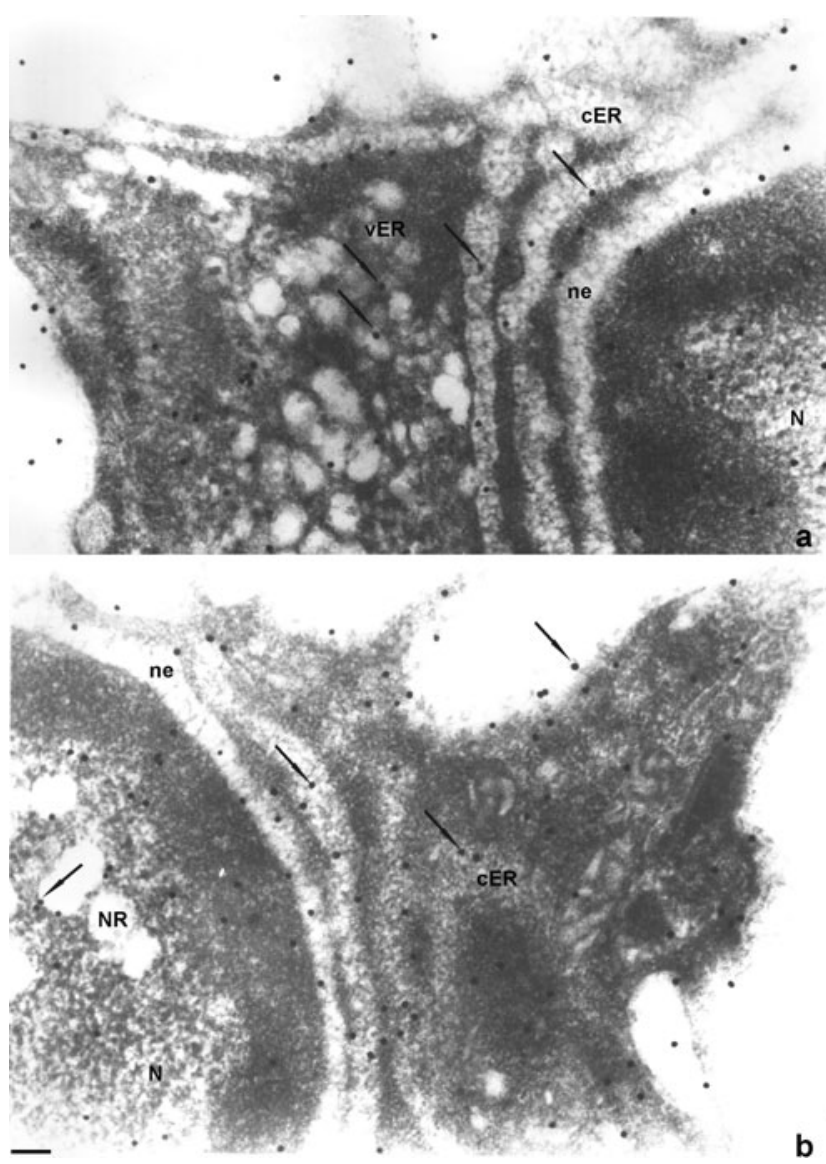

Fig. 2 Ultrastructure of spermatid at V stage of spermiogenesis in longitudinal section (immunogold technique for anti-CRT). a-b Arrows show localization of gold grains in particular spermatid compartment. $c E R$, endoplasmic reticulum cisternae; $v E R$, endoplasmic reticulum vesicles; $N$, nucleus; ne, nuclear envelope; $N R$, nuclear reticulum. Bar $=100 \mathrm{~nm}$

staining originating from the nucleus was most pronounced within condensed chromatin at its periphery just under the nuclear envelope and accounted for $27 \%$ of all protamine-type protein labelling in all cellular compartments (i.e., protamine-type proteins with CRT and protamine-type proteins alone comprise together 100\% of grains) (Table 2) and 79\% of all protamine-type proteins labelling in this part of a nucleus (grains from an individual cellular domains comprise 100\%) (Fig. 5). In noncondensed chromatin in the nuclear center and in the nuclear envelope, both types of grains were less numerous and respectively accounted for $13 \%$ and $4 \%$ of all protamine-type proteins labelling in all cellular compartments (Table 2) and for $68 \%$ and $54 \%$ of all protaminetype proteins labelling in this specific region (Fig. 5). In ER, stronger colocalization was observed in vesicles than in cisternae $-14 \%$ and $5 \%$ of overall protamine-type proteins, respectively (Table 2), and $50 \%$ and $63 \%$ of protamine-type proteins labelling in ER vesicles and cisternae (Fig. 5).
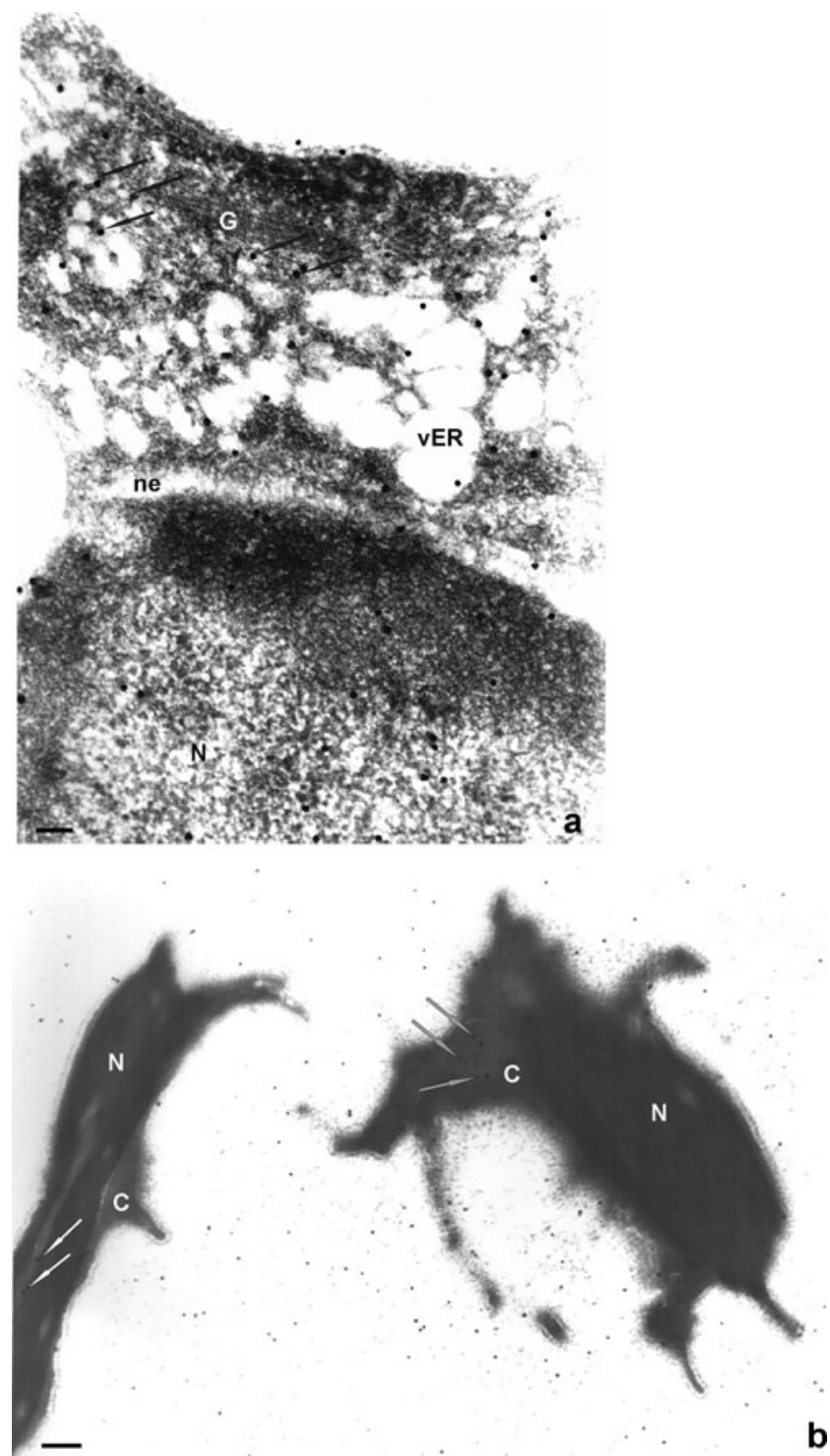

Fig. 3 Immunogold detection of CRT at stages V (a) and VIII (b) of $C$. vulgaris spermiogenesis. $C$, cytoplasm; $G$, Golgi apparatus; $N$, nucleus; ne, nuclear envelope; $v E R$, endoplasmic reticulum vesicles; black arrows indicate immunolabelling of Golgi apparatus; grey arrows, only a few immunosignals in cytoplasm, and white arrows, sparse gold grains between fibrils of chromatin within a crescent nucleus. Bar= $100 \mathrm{~nm}$ (a) and $b a r=250 \mathrm{~nm}(\mathbf{b})$

\section{Discussion}

In plants, there can be two or more CRT isoforms (Chen et al. 1994; Kwiatkowski et al. 1995; Nelson et al. 1997). Phylogenetic studies and expression analysis carried by Persson et al. (2003) revealed that Arabidopsis CRT1 and CRT2 form one group, whereas CRT3 constitutes another. These data strongly indicate that higher plants contain at least two distinct groups of CRTs: CRT1/CRT2 group and CRT3 group. Two CRT groups were also identified in the wheat genome (Jia et al. 2008). Western blot analyses of the 

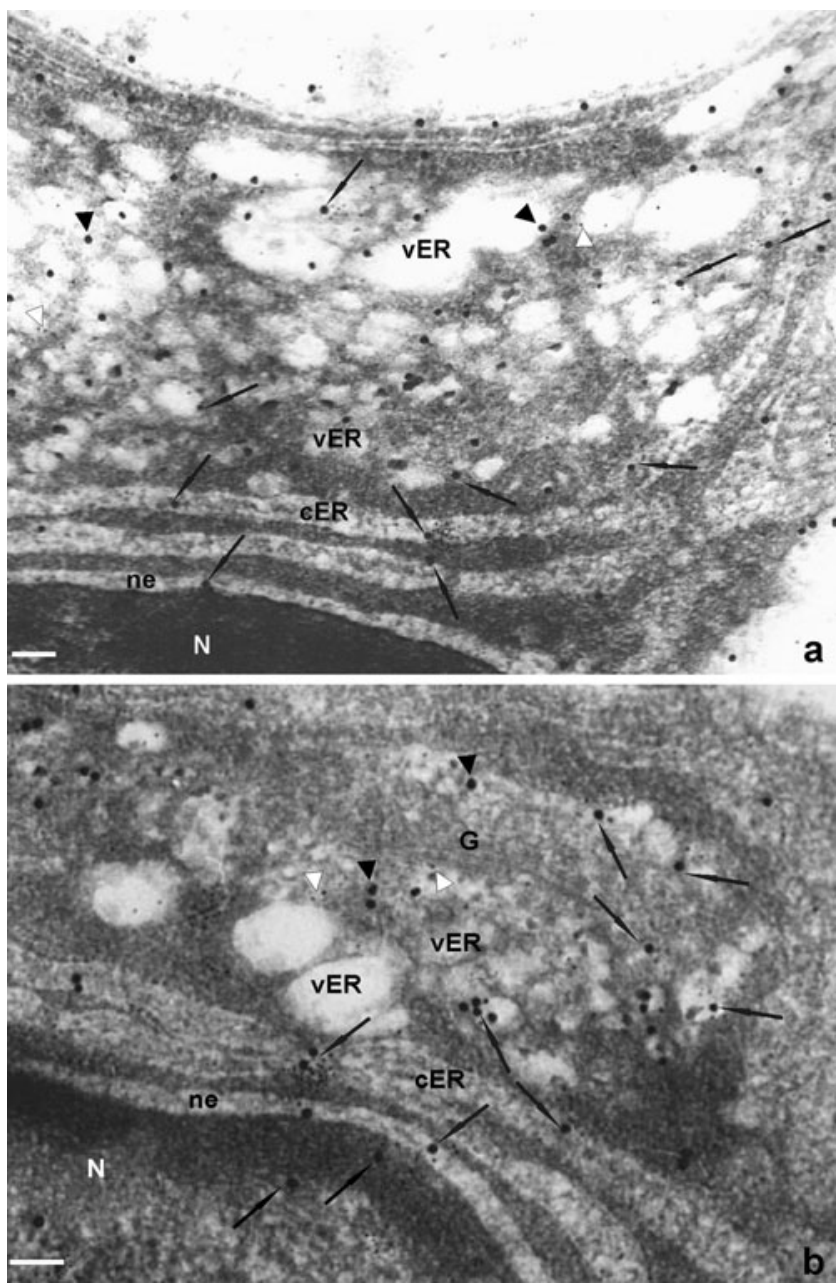

Fig. 4 Colocalization of protamine-type proteins (20 nm gold, black arrowheads) and CRT (10 nm gold, white arrowheads) at V stage of $C$. vulgaris spermiogenesis. a-b Arrows show common localization immunosignals for protamine-type proteins and calreticulin in particular spermatid compartment. $c E R$, endoplasmic reticulum cisternae; $v E R$, endoplasmic reticulum vesicles; $G$, Golgi apparatus; $N$, nucleus; $n e$, nuclear envelope; Bars $=100 \mathrm{~nm}$

extracts made of $C$. vulgaris antheridiostans at the $\mathrm{V}$ stage of spermiogenesis also showed CRT (55 kDa) and its isoform $(62 \mathrm{kDa})$. Some scientists using Western blot technique confirmed that CRT isoforms fall in the range of 48-62 kDa in different organisms including plants (Gonzalez et al. 2002; Lenartowska et al. 2009). Jia et al. (2009) noted that different isoforms of CRT might evolve to have some structural specificity favoring their targeting to different cellular parts for their respective functions. Postranslational modifications such as glycosylation, degradation of C-domain, and enzymatic modification of the glycan could mediate redistribution of CRT to other cellular compartments (Jethmalani et al. 1997; Navazio et al. 2002; Persson et al. 2003).

The use of animal antibodies against CRT in the studies on C. vulgaris was justified as Christensen et al. (2008) revealed that plant CRTs could substitute for animal CRTs,
Table 2 The percentage of protamine-type protein colocalization with CRT during the $\mathrm{V}$ stage of $C$. vulgaris spermiogenesis

\begin{tabular}{lll}
\hline Compartment & $\mathrm{P}+\mathrm{CRT}$ & $\mathrm{P}$ \\
\hline & Grains [\%] & Grains [\%] \\
Endoplasmic reticulum & & \\
Cisternae & $5 \pm 0.9$ & $3 \pm 0.45$ \\
Vesicles & $14 \pm 0.98^{\mathrm{a}}$ & $14 \pm 0.52^{\mathrm{a}}$ \\
Total & $19 \pm 0.82$ & $17 \pm 0.34$ \\
Whole nucleus & $44 \pm 0.48$ & $16 \pm 0.35$ \\
Nuclear envelope & $4 \pm 0.24$ & $3 \pm 0.1$ \\
Chromatin & & \\
Condensed & $27 \pm 1.53$ & $7 \pm 0.96$ \\
Noncondensed & $13 \pm 0.41$ & $6 \pm 0.5$ \\
Total & $40 \pm 0.79$ & $13 \pm 0.52$ \\
Cytoplasm and other organelles & $1 \pm 0.3$ & $3 \pm 0.42$ \\
\hline
\end{tabular}

The number of gold grains in particular C. vulgaris spermatid compartments is represented as percentage of the whole pool of grains regarded as $100 \%$; differences between percentage of protamine-type protein colocalization with calreticulin and protamine-type protein alone in the studied compartments are statistically significant taking $p \leq 0.05$ as the significance level; P+CRT - protamine-type proteins with CRT; P protamine-type proteins without CRT

$P+C R T$ protamine-type proteins with CRT, $P$ protamine-type proteins without CRT

${ }^{\mathrm{a}}$ These differences are not statistically significant

for example, with regard to protein abilities, showing that the animal sorting machinery was also functional for plant proteins. The researchers proved that basic CRT functions were conserved between the two kingdoms.

In plants, primary CRT localization was observed in ER lumen (Denecke et al. 1995; Napier et al. 1995; Opas et al. 1996; Lenartowska et al. 2002; 2009; Nardi et al. 2006). The present studies on $C$. vulgaris spermiogenesis resulted in the identification of the time and site of CRT presence. It was found to be the most abundant in ER at the onset of the exchange of nucleohistones into nucleoprotamines which is

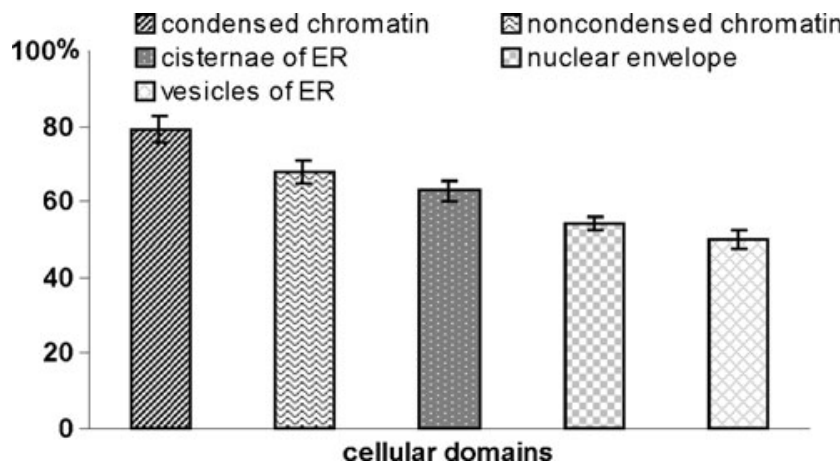

Fig. 5 The percentage of protamine-type protein colocalization with CRT within particular C. vulgaris spermatid compartments at V stage of spermiogenesis. Gold grains from an individual compartment comprise $100 \%$ 
indispensable for chromatin condensation and leads to the appearance of extremely condensed chromatin in mature spermatozoids.

Proper functioning of ER as a multifunctional system involved in protein transport is conditioned by various factors including the regulating mechanisms which control ER retention of the proteins, which are later transported and modified, and of chaperons, e.g., CRT, as well as of the enzymes conditioning protein maturation process. This involves coordinated synthesis of the cooperating components including those engaged in protein translocation. Unfortunately, little is known about the coordination of various phases of changes regarding ER (Stevens and Argon 1999; Chevet et al. 2001).

In ER lumen, there are numerous dissolved enzymatic proteins and molecular chaperons referred to as reticuloplasmins including immunoglobulin heavy-chain-binding protein BIP, protein disulphide isomerase PDI and CRT (Bedard et al. 2005; Hebert and Molinari 2007; Michalak et al. 2009).

In ER, chaperons transiently bind to non-folded or not fully folded proteins preventing their aggregation. Moreover, they slow down the folding process and increase the amount of properly folded proteins. CRT is involved in folding de novo synthesised proteins and glycoproteins (Michalak et al. 1999; Trombetta 2003). Present electron microscopic observations suggested that CRT could participate in translocation of de novo synthesized protamine-type proteins to a spermatid nucleus in C. vulgaris at the crucial V stage when the rearrangement of somatic nuclear proteins into generative ones started. It was revealed by a clearly noticeable colocalization of protamine-type proteins and CRT in a nucleus, nuclear envelope, and in extensive system of ER cisternae and vesicles which transport these proteins to a nucleus. Colloidal gold labelling coming from both antibodies, anti-CRT and antiprotamine-type proteins, during the $\mathrm{V}$ stage, significantly cumulated in a nucleus, especially at its periphery where condensed chromatin was present. Protamine-type protein labelling in this region was twofold greater than in the nuclei center filled with noncondensed chromatin (Popłońska et al. 2009). Moreover, in all studied cellular compartments, the percentage of protamine-type proteins/CRT colocalization was at least slightly or even significantly higher as compared to the protamine-type proteins alone. In addition, Lenartowska et al. $(2001,2009)$ clearly showed that rough ER was the site of CRT translation similarly as in the case of Chara protamine-type proteins (Popłońska et al. 2009).

In plants, e.g., in tobacco, it was observed that CRT stably complex with BIP was involved in protein folding (Crofts et al. 1998). CRT together with calnexin (CNX, a membrane chaperon similar to CRT) and Erp57 protein (PDI-type protein located in ER) constituted a CRT/CNX cycle which controlled quality and assembly of de novo synthesized proteins and glycoproteins (Trombetta 2003). Now it appears that complexes between ER-resident proteins including CRT could play a far more important role in protein folding (Gelebart et al. 2005). Confirming this, several chaperons, such as CNX1, CNX2, and SHEPHERD, were identified to highly coexpress with Arabidopsis CTRs (AtCTR1 and AtCRT2) (Obayashi et al. 2007), indicating that a tightly knit network of chaperonlike proteins may work together for protein folding in higher plants (Jia et al. 2009). Taking the above into consideration, as well as the present studies concerning alga spermiogenesis, we can suspect that CRT may be a chaperon involved in assembly and folding of de novo synthesized proteins in the studied species.

CRT also participates in reproductive process both in plants and animals. Enhancement of CRT expression was detected in zygotes and immature embryos of maize (Dresselhaus et al. 1996), in Arabidopsis flowers (Nelson et al. 1997), in maize sperm cells (Williams et al. 1997), and in tobacco anthers and pollen tubes (Nardi et al. 2006). CRT in Petunia can be involved in pollen-pistil interaction in vivo (Lenartowska et al. 2001). Moreover, immunoblot analysis of protein extracts from mature anthers, dry and germinated pollen, growing pollen tubes, and unpollinated/pollinated pistils revealed a strong expression of this chaperone (Lenartowska et al. 2009).

In animals, e.g., in mice and also in humans, two isoforms of CRT were revealed; one of them is strongly expressed in male reproductive organs - testes (Persson et al. 2002). This protein was also identified in human sperm neck (Naaby-Hansen et al. 2001), bull sperm neck (Ho and Suarez 2003), and in rat acrosome - both in spherical spermatids and in mature spermatozoids (Nakamura et al. 1993). It is worth noting that immunolabelling was significantly pronounced both in acrosome and in Golgi apparatus. It was observed that, during spermiogenesis in rat, CRT might be incorporated into acrosome via Golgi apparatus without glycosylation and might play an important role in spermatozoid function regulation, including their movement and in acrosome reaction (Nakamura et al. 1993). In Chara, despite the lack of acrosom, labelling of dictiosomes and Golgi vesicles was also observed. It is not surprising since, in plants, CRT was found in these cellular compartments earlier (Borisjuk et al. 1998; Navazio et al. 2002; Nardi et al. 2006). Moreover, in Chara colocalization of protamine-type proteins and CRT was observed in this organelle. Further studies will concentrate at elucidating the role of Golgi apparatus during Chara spermiogenesis.

Data from literature, as well as the present observations, support that CRT may take part in various biological processes, including spermiogenesis, both in animals and in plants.

Acknowledgments I am grateful to Dr. J. T. Polit from Department of Cytophysiology, University of Łódź, Poland, for her help and experience in Western blot technique.

This study was supported by grant from University of Łódź No. 505/393. 
Conflict of interest The author declares that she has no conflict of interest.

Open Access This article is distributed under the terms of the Creative Commons Attribution Noncommercial License which permits any noncommercial use, distribution, and reproduction in any medium, provided the original author(s) and source are credited.

\section{References}

Ausio J, Eirin-Lopez JM, Frehlick LJ (2007) Evolution of vertebrate chromosomal sperm proteins: implications for fertility and sperm competition. Soc Reprod Fertil Supl 65:63-79

Balhorn R (2007) The protamine family of sperm nuclear proteins. Genome Biol 8:227

Baumann O, Walz B (2001) Endoplasmic reticulum of animal cells and its organization into structural and functional domains. Int Rev Cytol 205:149-214

Bedard K, Szabo E, Michalak M, Opas M (2005) Cellular functions of endoplasmic reticulum chaperons calreticulin, calnexin and ERp57. Int Rev Cytol 245:91-121

Borisjuk N, Sitailo L, Adler K, Malysheva L, Tewes A, Borisjuk L, Manteuffel R (1998) Calreticulin expression in plant cells: developmental regulation, tissue specificity and intracellular distribution. Planta 206:504-514

Chen F, Hayes PM, Mulrooney DM, Pan A (1994) Identification and characterization of cDNA clones encoding plant calreticulin barley. Plant Cell 6:835-843

Chevet E, Cameron PH, Pelletier MF, Thomas DY, Bergeron JJM (2001) The endoplasmic reticulum: integration of protein folding, quality control, signaling and degradation. Curr Op Struct Biol $11: 120-124$

Christensen A, Svensson K, Persson S, Jung J, Michalak M, Widell S, Sommarin M (2008) Functional characterization of Arabidopsis calreticulin 1 a: a key alleviator of endoplasmic reticulum stress. Plant Cell Physiol 49:912-924

Crofts AJ, Leborgne-Castel N, Pesca M, Vitale A, Denecke J (1998) $\mathrm{BiP}$ and calreticulin form an abundant complex that is independent of endoplasmic reticulum stress. Plant Cell 10:813-824

Daban JR (2000) Physical constraints in the condensation of eukaryotic chromosomes. Local concentration of DNA versus linear packing ratio in higher order chromatin structures. Biochem 39:3861-3866

Dadoune J-P (2003) Expression of mammalian spermatozoal nucleoproteins. Microsc Res Tech 61:56-75

Denecke J, Carlsson LE, Vidal S, Hoglund AS, Ek B, van Zeijl MJ, Sinjorgo KM, Palva ET (1995) The tobacco homolog of mammalian calreticulin is present in protein complexes in vivo. Plant Cell 7:391-406

Dresselhaus T, Hagel C, Lorz H, Krantz E (1996) Isolation of a fulllength cDNA encoding calreticulin from a PCR library of in vitro zygotes of maize. Plant Mol Biol 31:23-34

Gelebart P, Opas M, Michalak M (2005) Calreticulin, a $\mathrm{Ca}^{2+}$-binding chaperone of the endoplasmic reticulum. Int J Biochem Cell Biol $37: 260-266$

Gonzalez E, Rico G, Mendoza G, Ramos F, Garcia G, Moratan P, Valdez A, Melendro EI, Ximenez C (2002) Calreticulin-like molecule in Trophozoites of Entamoeba histolytica HM1: (Swissprot: Accession P83003). AmJTrop Med Hyg 67(6):636-639

Hebert D, Molinari M (2007) In and out of the ER protein folding, quality control, degradation, and related human diseases. Physiol Rev 87:1377-1408
Hecht N, Behr R, Hild A, Bergmann M, Weidner W, Steger K (2009) The common marmoset (Callithrix jacchus) as a model for histone and protamine expression during human spermatogenesis. Hum Reprod 24:536-545

Ho H-Ch, Suarez SS (2003) Characterization of the intracellular calcium store at the base of the sperm flagellum that regulates hyperactivated motility. Biol Reprod 68:1590-1596

Jethmalani SM, Henle KJ, Gazitt Y, Walker PD, Wang SY (1997) Intracellular distribution of heat-induced stress glycoproteins. J Cell Biochem 66:98-111

Jia XY, Xu CY, Jing RL, Li RZ, Mao XG, Wang JP, Chang XP (2008) Molecular cloning and characterization of wheat calreticulin (CRT) gene involved in drought-stressed responses. J Exp Bot 59:739-751

Jia XY, He LH, Jing RL, Li RZ (2009) Calreticulin: conserved protein and diverse functions in plants. Physiol Plant 136:127-138

Kurtz K, Saperas N, Ausio J, Chiva M (2009) Spermiogenesis nuclear protein transitions and chromatin condensation. Proposal for an ancestral model of nuclear spermiogenesis. J Exp Zool (Mol Dev Evol) 312B:149-163

Kwiatkowska M (1996) Changes in ultrastructure of cytoplasm and nucleus during spermiogenesis in Chara vulgaris. Folia Histochem Cytobiol 34:41-56

Kwiatkowska M, Popłońska K (2002) Further ultrastructural research of Chara vulgaris spermiogenesis: endoplasmic reticulum, structure of chromatin, ${ }^{3} \mathrm{H}$-lysine and ${ }^{3} \mathrm{H}$-arginine incorporation. Folia Histochem Cytobiol 40:85-97

Kwiatkowska M, Kaźmierczak A, Popłońska K (2002) Ultrastructural, autoradiographic and electrophoretic examinations of Chara tomentosa spermiogenesis. Acta Soc Bot Pol 71:201-209

Kwiatkowska M, Popłońska K (2003) RER and protamine-type proteins during Chara tomentosa L. spermiogenesis. Acta Soc Bot Pol 72:5-9

Kwiatkowski BA, Zielińska-Kwiatkowska AG, Migdalski A, Kleczkowski LA, Wasilewska LD (1995) Cloning of two cDNAs encoding calnexin-like and calreticulin-like proteins from maize (Zea mays) leaves: identification of potential calcium-binding domains. Gene 165:219-222

Lenartowska M, Lenartowski R, Bednarska E (2001) Localization of the calreticulin gene mRNA in unpollinated and pollinated styles of Petunia hybrida Hort. J Appl Genet 42:15-20

Lenartowska M, Karaś K, Marshall J, Napier R, Bednarska E (2002) Immunocytochemical evidence of calreticulin-like protein in pollen tubes and styles of Petunia hybrida Hort. Protoplasma 219:23-30

Lenartowska M, Lenartowski R, Smoliński DJ, Wróbel B, Niedojadło J, Jaworski K, Bednarska E (2009) Calreticulin expression and localization in plant cells during pollen-pistil interactions. Planta 231:67-77

Li Z, Komatsu S (2000) Molecular cloning and characterization of calreticulin, a calcium-binding protein involved in the regeneration of rice cultured suspension cells. Eur J Biochem 267:737-745

Lim CO, Kim HY, Kim MG, Lee SI, Chung WS, Park SH, Hwang I, Cho MJ (1996) Expressed sequence tags of Chinese cabbage flower bud cDNA. Plant Physiol 111:577-588

McLay DW, Clarke HJ (2003) Remodelling the paternal chromatin at fertilization in mammals. Reproduction 125:625-633

Menegazzi P, Guzzo F, Baldan B, Mariani P, Treves S (1993) Purification of calreticulin-like protein(s) from spinach leaves. Biochem Biophys Res Commun 190:1130-1135

Michalak M, Corbett EF, Mesaeli N, Nakamura K, Opas M (1999) Calreticulin: one protein, one gene, many functions. Biochem $\mathrm{J}$ 344:281-292

Michalak M, Groenendyk J, Szabo E, Gold LI, Opas M (2009) Calreticulin, a multi-process calcium-buffering chaperone of the endoplasmic reticulum. Biochem J 417:651-666

Miller D, Brinkoworth M, Iles D (2010) Paternal DNA packaging in spermatozoa: more than the sum of its parts? DNA, histones, protamines and epigenetics. Reproduction 139:287-301 
Naaby-Hansen S, Wolkowicz MJ, Klotz K, Bush LA, Westbrook VA, Shibahara H, Shetty J, Coonrod SA, Reddi PP, Shannon J, Kinter M, Sherman NE, Fox J, Flickinger ChJ, Herr JC (2001) Colocalization of the inositol 1,4,5-trisphosphate receptor and calreticulin in the equatorial segment and in membrane bounded vesicles in the cytoplasmic droplet of human spermatozoa. Mol Hum Reprod 7:923-933

Nakamura M, Moriya M, Baba T, Michikawa Y, Yamanobe T, Arai K, Okinaga S, Kobayashi T (1993) An Endoplasmic Reticulum protein, calreticulin, is transported into acrosome of rat sperm. Exp Cell Res 205:101-110

Napier RM, Trueman S, Henderson J, Boyce JM, Hawes C, Fricker MD, Venis MA (1995) Purification, sequencing and functions of calreticulin from maize. J Exp Bot 46:1603-1613

Nardi CN, Feron R, Navazio L, Mariani P, Pierson E, Wolters-Arts M, Knuiman B, Mariani C, Derksen J (2006) Expression and localization of calreticulin in tobacco anthers and pollen tubes. Planta 223:12631271

Navazio L, Miuzzo M, Royle L, Baldan B, Varotto S, Merry AH, Hervey DJ, Dwek RA, Rudd PM, Mariani P (2002) Monitoring endoplasmic reticulum - to - Golgi traffic of a plant calreticulin by protein glycosylation analysis. Biochemistry 41:14141-14149

Nelson DE, Glaunsinger B, Bohnert HJ (1997) Abundant accumulation of the calcium-binding molecular chaperone calreticulin in specific floral tissues of Arabidopsis thaliana. Plant Physiol 114:29-37

Obayashi T, Kinoshita K, Nakai K, Shibaoka M, Hayashi S, Saeki M, Shibata D, Saito K, Ohta H (2007) ATTED-II: a database of coexpressed genes and cis elements for identifying co-regulated gene groups in Arabidopsis. Nucleic Acids Res 35:D863-D869

Oliva R, Dixon GM (1991) Verterbrate protamine genes and the histone-to-protamine replacement reaction. Prog Nucleic Acid Res Mol Biol 40:25-94

Opas M, Szewczenko-Pawlikowski M, Jass GK, Mesaeli N, Michalak M (1996) Calreticulin modulates cell adhesiveness via regulation of vinculin expression. J Cell Biol 135:1913-1923

Park BJ, Lee DG, Yu JR, Jung SK, Choi K (2001) Calreticulin, a calciumbinding molecular chaperone, is required for stress response and fertility in Caenorabditis elegans. Mol Biol Cell 12:2835-2845

Persson S, Rosenquist M, Sommarin M (2002) Identification of the novel calreticulin isoform (Crt2) in human and mouse. Gene 297:151-158

Persson S, Rosenquist M, Svensson K, Galvao R, Boss WF, Sommarin M (2003) Phylogenetic analyses and expression studies reveal two distinct groups of calreticulin isoforms in higher plants. Plant Physiol 133:1385-1396

Pogany GC, Corzett M, Feston S, Balhorn R (1981) DNA and protein content of mouse sperm. Implications regarding sperm chromatin structure. Exp Cell Res 136:127-136

Popłońska K (2002) Cytochemical studies on histone-type and protamine-type proteins during spermiogenesis in Chara vulgaris and Chara tomentosa. Folia Histochem Cytobiol 40:233-234
Popłońska K, Wojtczak A, Kwiatkowska M, Kaźmierczak A (2007) Cytochemical and immunocytochemical studies of the localization of histones and protamine-type proteins in spermatids of Chara vulgaris and Chara tomentosa. Folia Histochem Cytobiol 45:367374

Popłońska K, Kwiatkowska M, Wojtczak A, Polit J (2009) Immunogold evidence suggests that endoplasmic reticulum is the site of protamine type protein synthesis and participates in translocation of these proteins into the nucleus during Chara vulgaris spermiogenesis. Biol Reprod 80:572-580

Ramos L, van der Heijden GW, Derijck A, Berden JH, Kremer JA, van der Vlag J, de Boer P (2008) Incomplete nuclear transformation of human spermatozoa in oligo-astheno-teratospermia: characterization by indirect immunofluorescence of chromatin and thiol status. Hum Reprod 23:259-270

Rathke C, Baarends WM, Jayaramaiah-Raja S, Bartkuhn M, Renkawitz R, Renkawitz-Pohl R (2007) Transition from a nucleosome-based to a protamine-based chromatin configuration during spermiogenesis in Drosophila. J Cell Sc 120:1689-1700

Reynolds ES (1963) The use of lead citrate of high $\mathrm{pH}$ as an electronopaque stain in electron microscopy. J Cell Biol 17:208-212

Reynolds WF, Wolfe SL (1978) Changes in basic proteins during sperm maturation in a plant, Marchantia polymorpha. Exp Cell Res 116:269-273

Reynolds WF, Wolfe SL (1984) Protamines in plant sperm. Exp Cell Res 152:443-448

Šamaj J, Salaj J, Obert B, BaluškaF MD, Volkmann D (2008) Calreticulin mRNA and protein are localized to protein bodies in storage maize callus cells. Plant Cell Rep 27:231-239

Steger K (1999) Transcriptional and translational regulation of gene expression in haploid spermatids. Anat Embryol 199:471-487

Stevens FJ, Argon Y (1999) Protein folding in ER. Cell Develop Biol 10:443-454

Trombetta ES (2003) The contribution of N-glycans and their processing in the endoplasmic reticulum to glycoprotein biosynthesis. Glycobiology 13:77R-91R

Ward WS (1994) The structure of the sleeping genome: implications of sperm DNA organization for somatic cells. J Cell Biochem 55:77-82

Ward WS, Coffey DS (1991) DNA packing and organization in mammalian spermatozoa: comparison with somatic cells. Biol Reprod 44:569-574

Wouters-Tyrou D, Martinage A, Chevaillier P, Sautière P (1998) Nuclear basic proteins in spermiogenesis. Biochimie 80:117-128

Williams CM, Zhang G, Michalak M, Cass DJ (1997) Calciuminduced protein phosphorylation and changes in levels of calmodulin and calreticulin in maize sperm cells. Sex Plant Reprod 10:83-88

Worawittayawong P, Leigh C, Weerachatyanukul W, Manochantr S, Sobhon P, Breed WG, Sretarugsa P (2008) Changes in distribution of basic nuclear proteins and chromatin organization during spermiogenesis in the greater bandicoot rat, Bandicota indica. Cell Tissue Res 334:135-144 